\title{
Total Lipid Fractions and Fatty Acids Composition of Low-Fat Beef Burger
}

\author{
Mohamed K. E. Youssef ${ }^{1}$, Badway. M. D. Mostafa ${ }^{2}$, Magda A. A. Seliem, Alyaa M. A. Hashem²,* \\ ${ }^{1}$ Food Science and Technology Department, Faculty of Agriculture, Assiut University, Assiut, 71526, Egypt \\ ${ }^{2}$ Food Technology Research Institute, Agricultural Research Center, Giza, 12619, Egypt
}

\begin{abstract}
Low-fat beef burgers were produced with four different fat replacer (carrageenan, carboxymethyl cellulose, soy flour and goat meat) which were added at three levels $(0.3,0.5$ and 1\%), (1.5, 3 and 4.5\%), $(5,10$ and 15\%) and $(25,50$ and $100 \%$ ); respectively. Total lipid fractions were determined by using thin layer chromatography technique for beef burger in both raw and grilled state after 3 months of frozen storage. Data revealed that phospholipids contents were less and triglycerides contents were more in the studied beef burger. Low-fat beef burgers containing $0.3 \%$ carrageenan, $5 \%$ low-fat soy flour, $1.5 \%$ carboxymethyl cellulose, $25 \%$ goat meat $+75 \%$ beef and control sample (without any fat replacer) gained the highest sensory score, so it was important of determine the fatty acids composition of these samples by the end of frozen storage. Saturated fatty acids were $\mathrm{C}_{12: 0}, \mathrm{C}_{14: 0}, \mathrm{C}_{16: 0,}, \mathrm{C}_{17: 0}$ and $\mathrm{C}_{18: 0}$. Predominated, major monounsaturated fatty acids were $\mathrm{C}_{16: 1}, \mathrm{C}_{17: 1}, \mathrm{C}_{18: 1}$ and $\mathrm{C}_{20: 1}$; and the major polyunsaturated fatty acids were descendingly: $\mathrm{C}_{18: 2}, \mathrm{C}_{18: 3}$. Among these fatty acids, the fatty acid $\mathrm{C}_{18: 1}$ represented the highest relative percentage of all identified fatty acids.
\end{abstract}

Keywords lipid fractions, fatty acids, beef burger, goat meat, fat replacers, low-fat beef burger

\section{Introduction}

There had been an increased interest in recent years in ways to manipulate the fatty acid composition of meat. This is because meat is seen to be a major source of fat in the diet and especially of saturated fatty acids, which had been implicated in diseases associated with modern life, especially in developed countries. These include various cancers and especially coronary heart disease. The importance of the link between nutrition and health is a hot topic. Like other food-related sectors, the meat industry is undergoing major transformations, driven among other things by changes in consumer demands[1].

The Dietary Guideliness[2] recommended limiting total fat intake to not more than $30 \%$ of daily energy intake, with saturated fats no more than $10 \%$ and monounsaturated and polyunsaturated fats accounting for at least two- third of daily energy intake. Studies had shown that reduction in fat intake could result in $10 \%$ reduction of risk for heart disease, and if persons who are over weight lose weight in addition to modifying their diet, they could lower their risk for cardiovascular heart disease by $20 \%[3]$.

The fatty acid composition of meat had long been studied but still received a lot of attention in research because of its implications for human health. Besides a lower total fat

* Corresponding author:

alyaahashem@yahoo.com (Alyaa M. A. Hashem)

Published online at http://journal.sapub.org/fph

Copyright (C) 2012 Scientific \& Academic Publishing. All Rights Reserved intake, human nutritionists are recommending a higher intake of polyunsaturated fatty acids [4] and [5].

This investigation was carried out in an attempt to clarify the effect of adding fat replacers on total lipid fractions and fatty acids composition of low-fat beef burger after 3 months of frozen storage.

\section{Materials and Methods}

\subsection{Materials}

\subsubsection{Meat}

$40 \mathrm{~kg}$ of fresh lean beef (top round) muscle from old cows (3 years old) were obtained from Assiut slaughter house during March 2010. Visible fat and connective tissue were eliminated manually[6]. The lean beef samples were minced using meat mincer and was used for processing of low-fat beef burger.

\subsubsection{Goat meat (Chevon)}

$6.0 \mathrm{~kg}$ of fresh meat of goat was obtained from healthy 1 -yr-old goat (leg and shoulder cuts) purchased from Assiut local market during March 2010. The goat meat samples were minced using meat mincer and used for processing of low fat-beef burger.

\subsubsection{Fat replacers}

2.1.3.1. Carrageenan 
$72 \mathrm{~g}$ of GENUVISCO carrageenan type CSM-2 was obtained from Technogen Company at Dokii, Cairo, Egypt during March, 2010. It is a hydrocolloid consisting mainly of calcium, magnesium, potassium, and sodium sulphate ester of glactose and 3,6 anhydrogalactose co-polymers. It is soluble in cold water exhibiting a viscosity effect almost instantaneously after dispersion. The suspension was prepared by stirring $0.3,0.5$ and $1.0 \mathrm{~g}$ of carrageenan in $100 \mathrm{ml}$ iced water, then it was added to meat[7].

\subsubsection{Low-fat Soy Flour}

$1200 \mathrm{~g}$ of soy flour was purchased from the Food Technology Institute Agriculture Research Center- Giza, Egypt during March 2010. Powdered soy flour was rehydrated (by mixing one part of powdered soy flour with two parts of tap water) before addition to the meat[8].

\subsubsection{Carboxymethyl Cellulose Sodium Salt (CMC):}

$360 \mathrm{~g}$ of carboxmethyl cellulose (CMC) product No: 0385 was purchased from EL- Badry company at Assuit, Egypt during March, 2010. The suspensions were prepared by stirring 1.5, 3.0, $4.5 \mathrm{gm}$ of $\mathrm{CMC}$ in $100 \mathrm{ml}$ iced water, then it was added to meat[9].

\subsubsection{Spices}

Spices mixture was prepared using equal weights of clove, black pepper, Chinese cubeb, paprika and nutmeg that were obtained from the local market in Assiut during March 2010.

\subsubsection{Salt, Onion, Garlic and Parsely}

Salt, fresh onion, garlic and parsley were obtained from the local market in Assiut and used for preparation of beef burger during March, 2010.

\subsection{Methods}

\subsubsection{Preparation of Beef Burger Samples}

The burger formulae were formed using a patty marker (stainless steel model "Form") to obtain round discs $10 \mathrm{~cm}$ diameter and $0.5 \mathrm{~cm}$ thickness. After preparation of each formulae, the beef burger samples (each sample was $50 \mathrm{~g}$ ) were packed in polyethelene bags and were stored immediately in a deep freezer at $-20^{\circ} \mathrm{C}$ for up to three months where samples were required at zero time 1, 2 and 3 months for analyses before and after cooking. Basal beef burger formula included $85.75 \%$ minced beef, $1 \%$ salt, $0.5 \%$ onion, $0.25 \%$ garlic, $0.25 \%$ parsley, $0.25 \%$ mixed spices and $12 \mathrm{ml}$ iced water[7]. The suspensions of carrageenan $(0.3,0.5,1 \%)$, carboxymethyl cellulose $(1.5,3,4.5 \%)$, rehydrated soy flour $(5,10,15 \%)$, and minced goat meat $(25,50,100 \%)$ with different ratios were added to basal formula to prepare different low-fat beef burger treatments.

\subsubsection{Cooking of Beef Burger}

The beef burger studied samples were cooked using an electrical grill (Arcelik Mini Firin, Turkey) at $300^{\circ} \mathrm{C}$ (the distance between heat source and the sample was $4 \mathrm{~cm}$ ) for a total of $10 \mathrm{~min}, 6 \mathrm{~min}$ one side and $4 \mathrm{~min}$ in the other side [10].

\subsubsection{Chemical Analysis}

\subsubsection{Thin layer Chromatography Separation and Identification of Lipids}

Total lipids were extracted by chloroform: methanol mixture $(2: 1 \mathrm{v} / \mathrm{v})$ according to method described by[11] Silica gel G plates $(20 \times 20 \mathrm{~cm})$ were used for qualitative and quantitative determination of lipid fractions. Plates were developed in a mixture of petroleum ether, diethyl ether and glacial acid (80:20: 1, v/v/v). The lipid fractions were visualized by exposure to iodine vapor, the isolated fractions were identified on thin layer plates by comparing their $R_{f}$ values with that of known lipid standards. For quantitative analysis, the TLC chromatograms were scanned using densitometr modal (Seroscan elvi 146) and the data were analyzed by QS computer program analysis J scans.

\subsubsection{Determination of Fatty Acids Composition}

Preparation of methyl ester of fatty acids

The methyl esters of fatty acids were prepared from aliquots of total lipids using $5 \mathrm{ml} 3 \% \mathrm{H}_{2} \mathrm{SO}_{4}$ in absolute methanol and $2 \mathrm{ml}$ benzene as mentioned by[12]. The contents were heated for methanolysis at $90^{\circ} \mathrm{C}$ for 90 minute and after cooling, phase separation was performed by addition of $2 \mathrm{ml}$ distilled water and methyl ester were extracted with 2 $\mathrm{ml}$ aliquots of $5 \mathrm{ml}$ hexane each. The organic phase was removed, filtered through anhydrous sodium sulfate and then concentrated by using rotary evaporator.

- Gas liquid chromatography of methyl esters of fatty acids

The methyl esters of fatty acids were separated using a PYE Unicam Pro-GC gas liquid chromatography with a dual flame ionization, and were carried out on $(1.5 \mathrm{~m} \mathrm{x} 4 \mathrm{~mm})$ SP-2310 column, packed with 55\% cyanopropyl phenyl silicone dimensions. Column temperature: At first the temperature was programmed by increasing the temperature from $70-190^{\circ} \mathrm{C}$ at the rate of $8^{\circ} \mathrm{C} /$, minute. then isothermal for 10 minute at $190^{\circ} \mathrm{C}$.

The injector and detector temperatures were $250^{\circ} \mathrm{C}$ and $300^{\circ} \mathrm{C}$, respectively. Carrier gas: nitrogen at the rate 30 $\mathrm{ml} /$ minute., hydrogen flow rate $33 \mathrm{ml} /$ minute. and air flow rate $330 \mathrm{ml} /$ minute. The chart speed was $0.4 \mathrm{~cm} /$ minute. Peak identifications were established by comparing the retention times obtained with standard methyl esters. The areas under the chromatographic peak were measured with electronic integrator.

\section{Results and Discussion}

\subsection{Total Lipid Fractions of Beef Burger after 3 Months of Frozen Storage.}

The data presented in Table (1) and Figure (1) revealed the 
total lipid fractions of lipid extracted from beef burgers by the end of frozen storage. The data indicated that, the total lipids of beef burger were fractionated to seven fractions namely: phospholipids, monoglycerides, cholesterol, diglycerides, free fatty acids, triglycerides and hydrocarbons and using thin layer chromatographic technique (TLC). Such data are in good agreement with that previously reported by [13] and [14]. From the data presented in Table (1) it could be noticed that the phospholipids contents were less and triglycerides contents were more in the studied beef burger. Moreover, control sample had the highest contents of phospholipids as compared to other samples. This might be due to high amount of fat content of control samples.

\subsection{Total Lipid Fractions of Grilled Beef Burger after 3 Months of Frozen Storage.}

The data given in Table (2) and Figure (2) indicated that, grilling reduced the content of triglycerides and increased the contents of monoglycerides, diglycerides, cholesterol, free fatty acids and hydrocarbons in all samples. Such results are in agreement with [15] and [13] findings.

The increase of phospholipids content was in agreement with[16] findings for cooked beef and pork meat and[17] who reported that the use of dry heat (roasting) induced a slight increase in phospholipids of lamb meat. The decrease of triglycerides content was reported by[14] for roasting chicken meat. Meanwhile, the increase of monoglycerides, cholesterol, free fatty acids and hydrocarbon contents might be occurred during storage which coincide with[13] findings for chicken meat.

\subsection{Fatty Acids Composition of Low-Fat Beef Burger}

Data given in Table (3) outlined the fatty acids composition of high and low-fat beef burgers samples which gained the highest sensory score at all the time of storage. The data revealed that saturated fatty acids were $\mathrm{C}_{12: 0}, \mathrm{C}_{14: 0}, \mathrm{C}_{16: 0}$, $\mathrm{C}_{\text {17:0 }}$ and $\mathrm{C}_{18: 0}$. Predominated, major monounsaturated fatty acids were $\mathrm{C}_{16: 1}, \mathrm{C}_{17: 1}, \mathrm{C}_{18: 1}$ and $\mathrm{C}_{20: 1}$; and the major polyunsaturated fatty acids were descendingly: $\mathrm{C}_{18: 2}, \mathrm{C}_{18: 3}$. Among these fatty acids, the fatty acid $\mathrm{C}_{18: 1}$ represented the highest relative percentage of all identified fatty acids. The data are in agreement with[18] findings on beef.[19], investigating the fatty acids in beef patties found that the predominating fatty acid in the neutral lipids fraction was the $\mathrm{C}_{18: 1}$.

Table (1). Total lipid fractions of beef burger after adding fat replacers by the end of frozen storage. (\% of total lipids)

\begin{tabular}{|c|c|c|c|c|c|c|c|c|c|c|c|c|c|}
\hline \multirow[b]{2}{*}{ Lipid fractions } & \multirow[b]{2}{*}{ Control } & \multicolumn{3}{|c|}{ Carrageenan } & \multicolumn{3}{|c|}{$\begin{array}{l}\text { Carboxymethyl } \\
\text { cellulose }\end{array}$} & \multicolumn{3}{|c|}{ Soy flour } & \multicolumn{3}{|c|}{ Goat meat + Beef } \\
\hline & & $0.3 \%$ & $0.5 \%$ & $1 \%$ & $1.5 \%$ & $3 \%$ & $4.5 \%$ & $5 \%$ & $10 \%$ & $15 \%$ & $\begin{array}{c}100 \% \\
\text { goat } \\
\text { meat }\end{array}$ & $\begin{array}{c}50 \% \text { goat } \\
\text { meat }+50 \% \\
\text { beef }\end{array}$ & $\begin{array}{c}25 \% \text { goat } \\
\text { meat }+ \\
75 \% \text { beef }\end{array}$ \\
\hline Phospholipids & 9.36 & 5.08 & 5.80 & 5.20 & 4.80 & 5.35 & 5.47 & 4.97 & 6.30 & 7.00 & 4.00 & 5.57 & 5.72 \\
\hline Momoglycerides & 4.75 & 5.55 & 5.43 & 5.56 & 5.20 & 5.80 & 4.68 & 5.80 & 5.73 & 6.20 & 8.97 & 6.58 & 5.94 \\
\hline Cholesterol & 3.63 & 3.53 & 3.44 & 2.97 & 2.90 & 3.62 & 3.87 & 2.94 & 1.67 & 1.35 & 1.46 & 3.30 & 2.98 \\
\hline Diglycerides & 2.51 & 4.60 & 5.66 & 6.50 & 7.50 & 6.19 & 7.73 & 6.27 & 8.20 & 8.63 & 10.4 & 4.79 & 6.00 \\
\hline Free fatty acids & 7.43 & 7.98 & 8.00 & 9.80 & 7.30 & 8.87 & 9.11 & 5.00 & 4.83 & 3.21 & 4.73 & 6.25 & 6.57 \\
\hline Triglycerides & 70.74 & 69.40 & 67.77 & 66.58 & 68.50 & 66.72 & 65.94 & 72.22 & 69.50 & 69.78 & 66.47 & 69.83 & 68.97 \\
\hline Hydrocarbons & 1.58 & 3.86 & 3.90 & 3.39 & 3.80 & 3.45 & 3.20 & 2.80 & 3.77 & 3.83 & 3.97 & 3.68 & 3.82 \\
\hline
\end{tabular}

Hydrocarbons

Triglycerides

Free fatty acids

Diglycerides

Cholesterol

Monoglycerides

Phospholipids

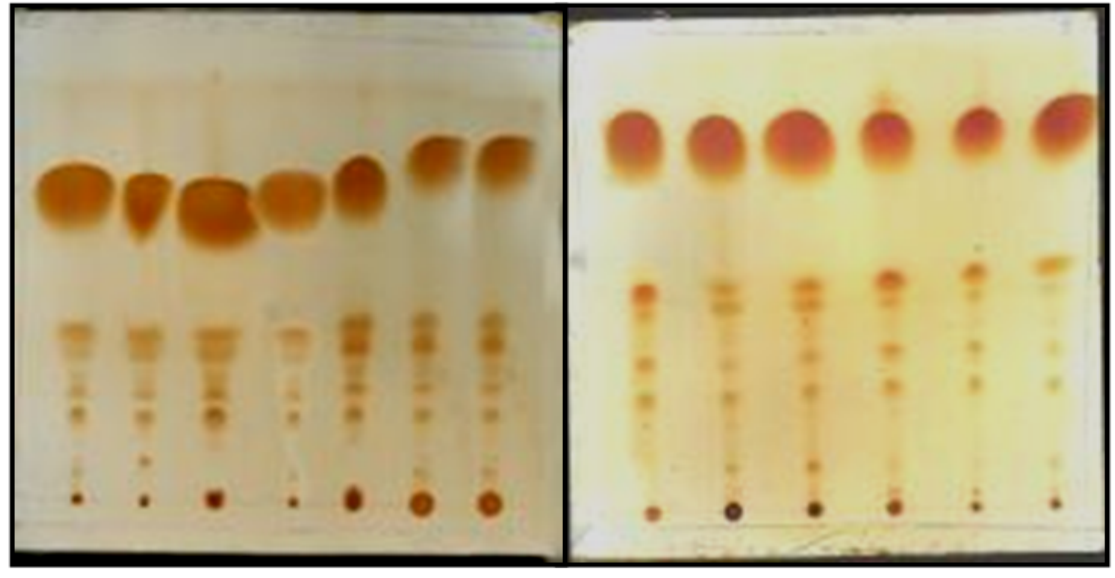

$\begin{array}{lll}1 & 2 & 3\end{array}$

$1=$ Control sample (without any fat replacers).

$2=$ Sample containing carrageenan at ratio $0.3 \%$.

$3=$ Sample containing carrageenan at ratio $0.5 \%$

$4=$ Sample containing carrageenan at ratio $1 \%$.

$5=$ Sample containing soy flour at ratio $5 \%$.

$6=$ Sample containing soy flour at ratio $10 \%$

$7=$ Sample containing soy flour at ratio $15 \%$

Figure (1). Total lipid fractions of beef burger after adding fat replacers by the end of frozen storage.

$8=$ Sample containing carboxymethyl cellulose at ratio $1.5 \%$.

$9=$ Sample containing carboxymethyl cellulose at ratio 3\%.

$10=$ Sample containing carboxymethyl cellulose at ratio $4.5 \%$

$11=$ Sample containing $100 \%$ goat meat

$12=$ Sample containing 50\% goat meat $+50 \%$ beef.

$13=$ Sample containing $25 \%$ goat meat $+75 \%$ beef. 
Table (2). Total lipid fractions of grilled beef burger after adding fat replacers by the end of frozen storage. (\% of total lipids)

\begin{tabular}{|c|c|c|c|c|c|c|c|c|c|c|c|c|c|}
\hline \multirow[b]{2}{*}{ Lipid fractions } & \multirow[b]{2}{*}{ Control } & \multicolumn{3}{|c|}{ Carrageenan } & \multicolumn{3}{|c|}{$\begin{array}{l}\text { Carboxymethyl } \\
\text { cellulose }\end{array}$} & \multicolumn{3}{|c|}{ Soy flour } & \multicolumn{3}{|c|}{ Goat meat+ Beef } \\
\hline & & $0.3 \%$ & $0.5 \%$ & $1 \%$ & $1.5 \%$ & $3 \%$ & $4.5 \%$ & $5 \%$ & $10 \%$ & $15 \%$ & $\begin{array}{c}100 \% \\
\text { goat } \\
\text { meat }\end{array}$ & $\begin{array}{c}50 \% \text { goat } \\
\text { meat }+50 \% \\
\text { beef }\end{array}$ & $\begin{array}{c}25 \% \text { goat } \\
\text { meat }+ \\
75 \% \text { beef }\end{array}$ \\
\hline Phospholipids & 9.80 & 5.25 & 6.00 & 5.80 & 4.97 & 5.68 & 5.78 & 5.10 & 6.70 & 7.20 & 4.63 & 5.93 & 6.00 \\
\hline Momoglycerides & 4.87 & 5.88 & 5.93 & 5.93 & 5.55 & 6.00 & 4.98 & 5.97 & 5.90 & 6.47 & 9.20 & 6.88 & 6.20 \\
\hline Cholesterol & 3.88 & 3.90 & 3.85 & 3.10 & 3.15 & 3.87 & 4.00 & 3.15 & 2.00 & 1.85 & 1.77 & 3.77 & 3.15 \\
\hline Diglycerides & 3.10 & 4.86 & 6.00 & 6.84 & 7.87 & 6.30 & 8.00 & 6.77 & 8.40 & 8.95 & 10.82 & 5.00 & 6.40 \\
\hline Free fatty acids & 8.95 & 8.22 & 9.66 & 10.0 & 8.00 & 9.00 & 9.85 & 6.00 & 5.13 & 4.89 & 5.00 & 6.67 & 6.87 \\
\hline Triglycerides & 67.51 & 67.90 & 64.46 & 64.75 & 66.45 & 65.37 & 63.89 & 69.91 & 67.92 & 66.64 & 64.28 & 67.86 & 67.38 \\
\hline Hydrocarbons & 1.89 & 3.99 & 4.10 & 3.58 & 4.10 & 3.78 & 3.50 & 3.10 & 3.95 & 4.00 & 4.30 & 3.89 & 4.00 \\
\hline
\end{tabular}

\section{Hydrocarbons}

Triglycerides

Free fatty acids

Diglycerides

Cholesterol

Monoglycerides phospholipid

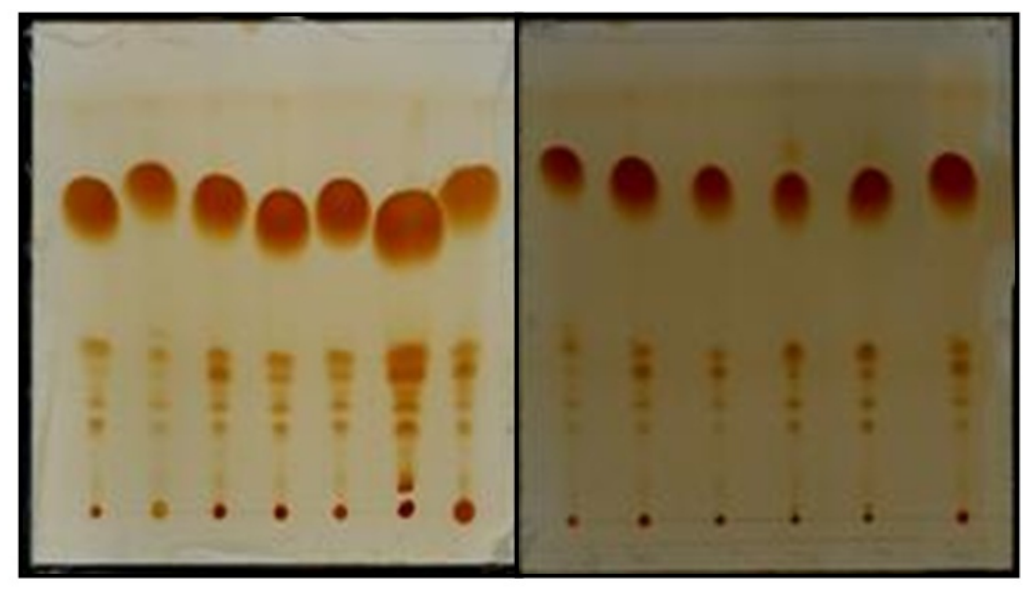

$$
\begin{array}{lllllllllllll}
1 & 2 & 3 & 4 & 5 & 6 & 7 & 8 & 9 & 10 & 11 & 12 & 13
\end{array}
$$

$1=$ Control sample (without any fat replacers).

$2=$ Sample containing carrageenan at ratio $0.3 \%$.

$8=$ Sample containing carboxymethyl cellulose at ratio $1.5 \%$.

$3=$ Sample containing carrageenan at ratio $0.5 \%$.

$4=$ Sample containing carrageenan at ratio $1 \%$.

$9=$ Sample containing carboxymethyl cellulose at ratio $3 \%$.

$10=$ Sample containing carboxymethyl cellulose at ratio $4.5 \%$.

$11=$ Sample containing $100 \%$ goat meat.

$5=$ Sample containing soy flour at ratio $5 \%$.

$6=$ Sample containing soy flour at ratio $10 \%$.

$7=$ Sample containing soy flour at ratio $15 \%$.

$12=$ Sample containing $50 \%$ goat meat $+50 \%$ beef.

$13=$ Sample containing $25 \%$ goat meat $+75 \%$ beef.

Figure (2). Total lipid fractions of grilled beef burger after adding fat replacers by the end of frozen storage

Table (3). Fatty acids composition of low-fat beef burger (as \% of total fatty acids)

\begin{tabular}{|c|c|c|c|c|c|c|}
\hline Fatty acids & structure & Control & CAR $0.3 \%$ & CMC $1.5 \%$ & Soy flour $5 \%$ & $25 \%$ goat meat $+75 \%$ Beef \\
\hline Lauric & $\mathrm{C}_{12: 0}$ & n.d & n.d & n.d & n.d & 0.08 \\
\hline Miristic & $C_{14: 0}$ & 3.33 & 3.24 & 3.11 & 3.32 & 3.25 \\
\hline Unknown1 & $\mathrm{C}_{\text {Unkown1 }}$ & 0.86 & 1.46 & 0.50 & 0.55 & 1.62 \\
\hline Unknown2 & $\mathrm{C}_{\text {Unkown2 }}$ & 1.73 & n.d & n.d & n.d & n.d \\
\hline Palmitic & $C_{16: 0}$ & 27.33 & 25.73 & 26.29 & 26.14 & 24.59 \\
\hline Palmitoleic & $C_{16: 1}$ & 3.11 & 3.53 & 3.57 & 3.62 & 4.11 \\
\hline Heptadecanoic & $C_{17: 0}$ & n.d & n.d & n.d & n.d & 1.43 \\
\hline Heptadecenoic & $C_{17: 1}$ & n.d & n.d & n.d & n.d & 0.87 \\
\hline Stearic & $C_{18: 0}$ & 19.44 & 13.75 & 18.44 & 14.40 & 12.61 \\
\hline Oleic & $C_{18: 1}$ & 37.78 & 41.45 & 41.71 & 41.84 & 42.30 \\
\hline Linoleic & $C_{18: 2}$ & 2.41 & 4.78 & 4.45 & 6.41 & 6.71 \\
\hline Linolenic & $C_{18: 3}$ & 1.19 & 1.28 & 1.93 & 1.65 & 2.43 \\
\hline Arachidic & $\mathrm{C}_{20: 0}$ & 1.27 & n.d & n.d & 1.33 & n.d \\
\hline Godaleic & $\mathrm{C}_{20: 1}$ & 1.55 & n.d & n.d & 0.74 & n.d \\
\hline Unknown3 & $\mathrm{C}_{\text {Unknown3 }}$ & n.d & 4.78 & n.d & n.d & n.d \\
\hline Total & & 100 & 100 & 100 & 100 & 100 \\
\hline Unknown & & 2.59 & 6.24 & 0.50 & 0.55 & 1.62 \\
\hline SFA & & 51.37 & 42.72 & 47.84 & 45.19 & 41.96 \\
\hline USFA & & 46.06 & 51.04 & 51.66 & 54.26 & 56.42 \\
\hline $\mathrm{S} / \mathrm{U}$ ratio & & 1.12 & 0.84 & 0.93 & 0.83 & 0.74 \\
\hline
\end{tabular}

- $\mathrm{n} \cdot \mathrm{d}=$ Not detected.

- $\mathrm{CAR}=$ Carrageenan.

- $\mathrm{CMC}=$ Carboxymethyl cellulose.

- $\mathrm{SFA}=$ Saturated fatty acids

- USFA= Unsaturated fatty acids.

- $\mathrm{S} / \mathrm{U}$ ratio= Saturated fatty acids/ Unsaturated fatty acids ratio. 
From the data presented results in Table (3) it could be observed that the sample containing $25 \%$ goat meat $+75 \%$ beef had higher contents of unsaturated fatty acids than other samples. This observation might be due to that this sample containing goat meat had a higher percentage of oleic acid $\mathrm{C}_{18: 1}$ about (42.30\%) and a higher percentage of polyunsaturated fatty acids than other samples. Such results are in agreement with[20] which showed that goat lipids were higher in polyunsaturated fatty acids (i.e., $\mathrm{C}_{18: 2}, \mathrm{C}_{18: 3}$ and $\mathrm{C}_{20: 4}$ ) than noted in lamb and beef.

It could be noticed that the control sample had higher contents of $\mathrm{C}_{14: 0}, \mathrm{C}_{16: 0}, \mathrm{C}_{18: 0}$ and $\mathrm{C}_{20: 0}$ and less $\mathrm{C}_{16: 1}, \mathrm{C}_{18: 2}$ and $\mathrm{C}_{18: 3}$ than other studied samples. Such finding might be due to the higher fat content of control sample than other low-fat beef burgers samples. The data are in agreement with[21] who found that beef samples had higher contents of $\mathrm{C}_{14: 0}, \mathrm{C}_{16: 0}$, and $\mathrm{C}_{18: 0}$; and less $\mathrm{C}_{16: 1}, \mathrm{C}_{18: 2}, \mathrm{C}_{18: 3}, \mathrm{C}_{20: 4}$ and $\mathrm{C}_{22: 6}$ than other samples. [22] showed that beef fat was a significant source of saturated fatty acids.

From the results given in Table (3) it could be observed that low-fat beef burgers were enriched with unsaturated fatty acids than saturated fatty acids in all samples except that in control sample which had a high content of fat. [23] investigating the effect of type of emulsifiers and antioxidants on oxidative stability color and fatty acid profile of low-fat beef burgers enriched with unsaturated fatty acids and phytosterols, found that the fatty acids profile of low-fat beef burgers had a high monounsaturated fatty acids content with oleic acid. On other hand, unsaturated fatty acids have various health benefits including ability to reduce arteriosclerosis and thrombotic tendency of blood, the activity associated mainly with n-3 polyunsaturated fatty acids, especially $\mathrm{C}_{18: 3}[24]$.

\section{Conclusions}

On the basis of the above-mentioned data the fatty acids profile of these low-fat meat burgers had a high monounsaturated fatty acids content with oleic acid comprising more than the other fatty acids and this is necessary to decrease cholesterol and the risk of heart disease. The low-fat beef burger recommended to include in diet regimen of both over weight and obese persons as well as diabetic, hyper cholesterolemic and hyperlipidimemic patients.

\section{ACKNOWLEDGEMENTS}

The authors wish to express the acknowledgement for Food Science and Technology Department, Faculty of Agricultural, and Meat and Fish Department, Food Technology Research Institute, Agricultural Research Center for providing the necessary laboratory facilities to accomplish the present work.

\section{REFERENCES}

[1] Jiménez-Colmenero, F. (2007). Healthier lipid formulation approaches in meat-based functional foods. Technological options for replacement of meat fats by non-meat fats. Trends in Food Science \& Technology, 18, 567-578.

[2] USDA and U.S.D.H.H.S. (1995). Nutrition and your health: Dietary Guidelines for Americans $4^{\text {th }}$ ed., Home and Garden Bulletin, No.232., U.S. Dept. Agriculture and U.S. Dept. Health and Human Service, Washington, D.C., 129pp.

[3] Latta, S. (1990). Dietary fats: New directions in research. Inform, 1(4), 238-258.

[4] Department of Health. (1994). Nutritional aspects of cardiovascular disease. Report on health and social subjects (Vol. 46). London: HMSO.

[5] Voedingsaanbevelingen voor België, (2000). De Hoge Gezondheidsraad, Ministerie van Sociale zaken, Volksgezondheid en Leefmilieu, Brussel, Belgie, 81 p.

[6] Martínez, B., Miranda, J. M., \& Vázquez, B. I., Fente, C. A., Franco, C. M., \& Jose L. Rodríguez, J. L., Cepeda, A. (2009). Development of Hamburger Patty with Healthier Lipid Formulation and Study of its Nutritional, Sensory, and Stability Properties. Food Bioprocess Technol, DOI 10.1007/s11947-009-0268-x.

[7] Ali, M. A. (2008). Effect of Processing and Cooking Methods on Chemical Biological and Microbiological Properties of Low-Fat Meat Products. Ph. D. Thesis Food Science and Technology Dept., Faculty of Agric., Cairo Univ., Egypt.

[8] El- Naggar, S. M. (1999). Production and Evaluation of Low-fat Meat Products. M. Sc Thesis, Food Science and Technology Dept., Faculty of Agric., Ain Shams Univ., Egypt.

[9] Gomez-Díaz, D., Navaza, J. M., \& Quintans-Riveiro, L. C. (2008). Intrinsic viscosity and flow behaviour of Arabic gum aqueous solutions. International J. Food Properties, 11, 773-780.

[10] Turhan, S., Sagir, I. and Ustun, N. S. (2005). Utilization of hazelnut pellicle in low-fat beef burgers. Meat Sci., 71, 312-316.

[11] Kates, M. (1972). Techniques of lipidology. Isolation, Analysis and Identification of lipids. North Holland publishing Co, Amsterdam.

[12] Rossell, J. B., King, B. and Downes, M. J. (1983). Detection of adulteration. J. Am. Oil. Chem. Soc., 60, 333.

[13] Youssef, M. K. E. and Rashwan, M. R. A. (1989). Changes in lipid fractions, phospholipids fractions and fatty acid composition in Hubbard chicken tissues during boiling and frying. Fleischwirtschaft, 69(3), 377-379.

[14] Khalifa, A. H. A. (1995). Chemical and Technological Studies on Poultry Meats. Ph. D. Thesis, Food Science and Technology Dept. Faculty of Agric., Assiut Univ., Egypt.

[15] Youssef, M. K. E., Abou-El-Hawa, S. H. and El-Rify, M. N. (1983). Changes in lipid fractions of chicken broiler tissues and their fatty acid composition during chilling, Freezing and cooking. First African Conference of Food Science and Technology. 14-17 November, Cairo, Egypt. 
[16] Campbell, A. M. and Turrki (1967). The lipids of raw and cooked ground beef and pork. J. Food Sci., 32, 143.

[17] El- Banna, H. A. (1980). Studies on the Effect of Freezing, Frozen Storage and Cooking on the Chemical Changes and Quality Characteristics of Lamb Meat. M. Sc. Thesis, Faculty of Agric., Cairo Univ., Egypt.

[18] Ingene, J. O., and Pearson, A. M. (1979). Role of phospholipids and triglycerides in warmed over flavor development in meat model system, J. Food Sci., 44, 1286.

[19] Gokalp, H. Y. (1978). Lipid oxidation and alteration of carbonyls and their relationship with the organoleptic evaluation of frozen stored beef patties, Diss. Abst. Int., B38(8), 3617.

[20] Banskalieva, V., Sahlub, T. and Goetsch, A. L. (2000). Fatty acid composition of goat muscles and fat depots: a review. Small Ruminant Res., 37, 255-268.
[21] Mohamed, H. A. A. (2005). Low Fat Meat Products as Prepared from Ostorich and other Reduced Fat Beef. Ph. D. Thesis, Nutrition and Food Science Dept., Faculty of Home Economics, Menufiya, Univ., Egypt.

[22] Muchenje, V., Dzama, K., Chimonyo, M., Strydom, P. E., Hugo, A., \& Raats, J. G. (2009).Some biochemical aspects pertaining to beef eating quality and consumer health: A review. Food Chem., 112, 279-289.

[23] Pennisi Forell, S. C., Ranalli, N., Zaritzky, N. E., Andrés, S. C. and Califano, A. N. (2010). Effect of type of emulsifiers and antioxidants on oxidative stability, colour and fatty acid profile of low-fat beef burgers enriched with unsaturated fatty acids and phytosterols. Meat Sci., 86, 364-370.

[24] Connor, W.E. (2000). Importance of $n-3$ fatty acids in health and disease. Am. J. Clin. Nutr. 71, 171S-175S 